\title{
GAMBARAN PENGGUNAAN VITAMIN C SEBAGAI IMUNOMODULATOR PADA PASIEN DEWASA DENGAN COVID- 19: STUDI LITERATUR
}

\author{
Luh Tuti Suryati ${ }^{1 *}$, Debby Juliadi ${ }^{1}$

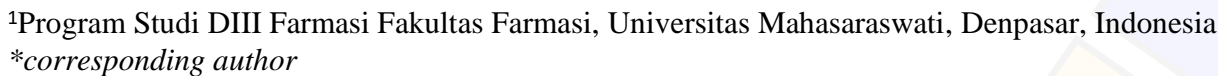

Email: tutisurya00@gmail.com

Diterima : 18 Agustus 2021

Direvisi : 8 September 2021

Publikasi : 20 Oktober 2021

doi:10.52216/jfsi.vol4no2p31-40

\begin{abstract}
Corona virus or COVID 19 is a virus that causes disease in animals or humans. COVID-19 more often attacks the respiratory tract. Improving the immunity of COVID-19 patients is very much needed because the treatment for COVID-19 has not been found. Vitamin $C$ is a vitamin that can prevent and treat respiratory infections by enhancing various immune cell functions. Vitamin $C$ acts as a powerful antioxidant and helps replace damaged cells so it can help with COVID-19. This literature study aims to determine the use of vitamin $C$ as an immunomodulator in adult COVID-19 patients. The data collection method was obtained by reviewing 10 journals using Google Scholar and Pubmed using Englishlanguage journals. The keywords used are vitamin C, COVID-19, treatment. The results obtained in the form of intravenous vitamin $C$ with a dose of can improve the lives of COVID-19 patients by increasing the immunity of infected patients. This can be seen from the inhibition of the development of cytokines and an increase in lymphocytes and CD4+ $T$ cells. In addition, it improves the patient's respiratory function with an increase in $\mathrm{PiO}_{2} / \mathrm{FiO}_{2}$.
\end{abstract}

Keywords: Immunity, COVID-19, vitamin C

\section{Intisari}

Virus corona atau COVID 19 merupakan virus yang menyebabkan penyakit pada hewan atau manusia. COVID-19 lebih sering menyerang saluran pernapasan. Peningkatan imunitas pasien COVID-19, sangat diperlukan dikarenakan pengobatan COVID-19 belum ditemukan. Vitamin C merupakan vitamin yang dapat mencegah dan mengobati infeksi pernapasan dengan meningkatkan berbagai fungsi sel kekebalan tubuh. Vitamin $C$ bertindak sebagai antioksidan kuat dan membantu mengganti sel-sel yang rusak sehingga dapat membantu pada COVID-19. Studi literatur ini bertujuan untuk mengetahui penggunaan vitamin C sebagai imunomodulator pada pasien dewasa COVID-19. Metode pengambilan data diperoleh dengan mereview 10 jurnal dengan menggunakan google scholar dan Pubmed dengan menggunakan jurnal berbahasa inggris. Adapun kata kunci yang digunakan yaitu vitamin C, COVID19, treatment. Hasil yang diperoleh berupa pemberian vitamin $C$ secara intravena dengan dosis tinggi dapat meningkatkan perbaikan kehidupan pasien COVID-19 dengan meningkatkan kekebalan tubuh pasien yang terinfeksi. Hal tersebut terlihat dari dihambatnya perkembangan dari sitokin dan meningkatkan limfosit serta sel T CD4+. Selain itu, meningkatkan fungsi pernafasan pasien dengan terjadi peningkatan pada $\mathrm{PiO}_{2} / \mathrm{FiO}_{2}$.

Kata kunci: Imunitas, COVID-19, vitamin C 


\section{Pendahuluan}

Virus corona atau COVID 19 merupakan virus yang menyebabkan penyakit pada hewan atau manusia. Penyebaran virus ini, diduga dilakukan oleh kelelawar dan hewan lain yang dimakan oleh manusia. Virus ini memiliki tingkat perkembangan dan penyebaran yang cepat dengan tingkat infeksi yang tinggi (Hidayah et al., 2020). Waktu inkubasi rata-rata mulai dari lima sampai enam hari dengan masa inkubasi terpanjang dua minggu. Penularan virus ini melalui aerosol, droplet dan penularan melalui fecal-oral yang telah dibedakan (Rothan \& Byrareddy, 2020).

WHO menyatakan bahwa COVID-19 merupakan pandemi global pada tanggal 11 Maret 2020 (Yang et al., 2020). Hal ini, dikarenakan terdapat penambahan kasus COVID-19 yang terjadi dengan cepat sampai ke antar negara (Rahman \& Bahar, 2020). Di Indonesia kasus mengumumkan 311.176 kasus terkonfirmasi COVID-19 dengan kasus meninggal sebanyak 11.374 dan sembuh sebanyak 236.437 dari 34 provinsi (Kemenkes RI, 2020).

COVID-19 memiliki gejala seperti demam, flu, dan dyspnea. Dari gejala tersebut menunjukkan bahwa virus ini lebih sering menyerang saluran pernapasan (Rothan \& Byrareddy, 2020). Pada kasus berat, COVID-19 dapat menyebabkan pneumonia, sindrom pernapasan akut, gagal ginjal, dan bahkan kematian (Kemenkes RI, 2020).

Peningkatan imunitas pada pasien COVID19, sangat diperlukan dikarenakan pengobatan COVID-19 secara farmakologis belum ada. Sehingga, diperlukan imunomodulator untuk melawan berbagai infeksi, namun agar diperoleh dari kekebalan sel diperlukan vitamin $\mathrm{C}$ (Liu et al., 2020).

Vitamin C memiliki peran utama dalam menjaga kekebalan fungsi sel (Maggini et al., 2007). Vitamin C dipercaya mampu mencegah dan mengobati infeksi pernapasan dengan meningkatkan berbagai fungsi sel kekebalan tubuh. Vitamin $\mathrm{C}$ bertindak sebagai antioksidan kuat dan membantu mengganti sel-sel yang rusak, sehingga dapat membantu pada SARS-Co-V-2 dan infeksi virus lainnya (Kirchdoerfer et al., 2016). Selain itu, vitamin $C$ dapat membuang radikal bebas dalam plasma dan melindungi sel terhadap kerusakan oksidatif yang disebabkan oleh reactive oxygen species (ROS). Pemberian vitamin $C$ melalui intravena dapat juga menurunkan infeksi virus (Fowler et al., 2019). Oleh karena itu, review jurnal ini bertujuan untuk mengetahui penggunaan vitamin $\mathrm{C}$ sebagai imunomodulator pada pasien dewasa dengan COVID-19.

\section{Metode Penelitian}

Metode yang digunakan dalam review jurnal ini yaitu studi literatur dengan memanfaatkan media internet dengan search engine berupa google scholar dan Pubmed. Jurnal yang digunakan berupa jurnal berbahasa inggris yang telah ditranslate ke dalam bahasa Indonesia. Kriteria sumber literatur yang digunakan yaitu 2 tahun terakhir (tahun 2020 sampai dengan 2021) dengan jurnal yang ditelusuri merupakan jurnal mengenai penggunaan vitamin $\mathrm{C}$ pada pasien dewasa dengan COVID-19. Pencarian literatur menggunakan kata kunci yang digunakan dalam penelusuran jurnal yaitu vitamin C, COVID 19, dan treatment.

\section{Hasil dan Pembahasan}

Hasil studi literatur meliputi 10 jurnal yang telah memenuhi kriteria yaitu mengenai penggunaan vitamin $\mathrm{C}$ pada pasien COVID-19. Pada masing-masing jurnal menggunakan vitamin C dalam dosis yang berbeda-beda, tetapi samasama dalam dosis tinggi. Dalam rangka meningkatkan kehidupan pasien dewasa COVID19. Adapun, hasil studi literatur terdapat pada Tabel 1.

Berdasarkan studi literatur pada 10 jurnal dapat diketahui bahwa pasien dengan kondisi berat dan kritis diberikan vitamin $\mathrm{C}$ dosis tinggi secara intravena atau high-dose intravenous vitamin $C$ (HDIVC) menunjukkan terjadi penurunan kadar serum $C$-reactive protein (CRP) (Zhao, Ling, et al., 2021; Zhao, Liu, et al., 2021). Penurunan kadar serum C-reactive protein (CRP) yang cepat menunjukkan pemberian vitamin $C$ dosis tinggi secara intravena bermanfaat dalam menurunkan respons inflamasi pasien COVID-19 (Williams et al., 2019). 
Tabel 1. Hasil Studi Literatur Penggunaan Vitamin C pada Pasien Dewasa dengan COVID-19

\begin{tabular}{|c|c|c|c|c|c|c|}
\hline No & Judul & $\begin{array}{c}\text { Tahu } \\
\text { n }\end{array}$ & Metode & Populasi & Sampel & Hasil Studi Literatur \\
\hline 1. & $\begin{array}{l}\text { Aspek } \\
\text { menguntungkan } \\
\text { dari vitamin C } \\
\text { intravena dosis } \\
\text { tinggi pada } \\
\text { pasien } \\
\text { dengan } \\
\text { pneumonia } \\
\text { COVID-19 } \\
\text { dalam kondisi } \\
\text { parah: } \\
\text { retrospektif } \\
\text { studi seri kasus } \\
\text { (Zao et al., } \\
\text { 2020). }\end{array}$ & 2020 & $\begin{array}{l}\text { Penelitian studi } \\
\text { kasus } \\
\text { retrospektif }\end{array}$ & \begin{tabular}{lr}
\multicolumn{2}{c}{ Semua } \\
pasien yang \\
dirawat di \\
Pusat Klinik \\
Kesehatan \\
Masyarakat \\
Shanghai \\
dari 22 \\
Januari 2020 \\
hingga 11 \\
April 2020
\end{tabular} & \begin{tabular}{lrr}
\multicolumn{1}{c}{ Pasien } & di atas 18 \\
tahun & didiagnosis \\
pneumonia & COVID-19, \\
pasien yang & kritis \\
menderit & penyakit \\
tambahan, & terdaftar \\
pasien menerima HDIVC \\
dalam 24 jam & setelah \\
penyakit parah, tidak \\
hamil dan & tidak \\
menderita tumor ganas.
\end{tabular} & $\begin{array}{l}\text { Hasil dari penelitian ini } \\
\text { yaitu dosis vitamin C } \\
\text { sebesar } 162,7 \quad \mathrm{mg} / \mathrm{kg} \\
\text { untuk kondisi berat dan } \\
178.6 \quad \mathrm{mg} / \mathrm{kg} \text { untuk } \\
\text { kondisi kritis. }\end{array}$ \\
\hline 2. & $\begin{array}{l}\text { Infus vitamin } C \\
\text { dosis tinggi } \\
\text { untuk } \\
\text { pengobatan } \\
\text { COVID-19 } \\
\text { yang sakit kritis } \\
\text { (Zhang et al., } \\
\text { 2020). }\end{array}$ & 2020 & $\begin{array}{l}\text { Penelitian ini } \\
\text { menggunakan } \\
\text { uji coba acak. }\end{array}$ & \begin{tabular}{l}
\multicolumn{2}{c}{ Semua } \\
pasien di \\
ICU Rumah \\
Sakit \\
Zhongnan \\
Universitas \\
Wuhan, \\
Rumah Sakit \\
Leishenshan, \\
dan Rumah \\
Sakit Taihe \\
dari tanggal \\
14 Februari \\
2020 sampai \\
$29 \quad$ Maret \\
2020.
\end{tabular} & $\begin{array}{l}\text { Pasien dengan umur } \\
\text { di atas } 18 \text { tahun dan di } \\
\text { bawah } 80 \text { tahun dengan } \\
\text { RT-PCR positif, } \\
\text { terkonfirmasi pneumonia, } \\
\text { memiliki } \mathrm{PaO}_{2} / \mathrm{FiO}_{2}(\mathrm{P} / \mathrm{F}) \\
<300 \mathrm{mgHg} \text {, dan terdaftar } \\
\text { pada ICU. }\end{array}$ & $\begin{array}{l}\text { Hasil penelitian } \\
\text { diperoleh pasien COVID- } \\
19 \text { diberikan HDIVC } \\
\text { sebesar } 24 \mathrm{~g} \text { vitamin C per } \\
\text { hari. Pasien diinfus } \\
\text { dengan } 12 \mathrm{~g} \text { vitamin } \mathrm{C} \\
\text { dilarutkan dalam } 50 \mathrm{~mL} \\
\text { air bakteriostatik setiap } 12 \\
\text { jam pada kecepatan } 12 \\
\text { ml/jam dengan pompa } \\
\text { infus selama } 7 \text { hari. }\end{array}$ \\
\hline 3. & $\begin{array}{l}\text { Infus intravena } \\
\text { vitamin C dosis } \\
\text { tinggi dalam } \\
\text { pengobatan } \\
\text { pasien COVID- } \\
19 \text { (Huang et } \\
\text { al., 2021). }\end{array}$ & 2021 & $\begin{array}{l}\text { Penelitian sesuai } \\
\text { dengan } \\
\text { penelusuran } \\
\text { data elektronik } \\
\text { pada Pubmed, } \\
\text { Embase, } \\
\text { Cochrane } \\
\text { Central Register } \\
\text { of Controlled } \\
\text { Trials, Web } \\
\text { sains, basis data } \\
\text { Infrasturktur } \\
\text { Pengetahuan } \\
\text { Nasional } \\
\text { Tiongkok, basis } \\
\text { data Wanfang } \\
\text { Tiongkok, dan } \\
\text { Sastra Biomedis } \\
\text { Tiongkok basis } \\
\text { data dengan } \\
\text { studi acak uji } \\
\text { coba terkontrol } \\
\text { pada infus } \\
\text { vitamin C dosis } \\
\text { tinggi dalam }\end{array}$ & $y$ & $\begin{array}{l}\text { Sampel pada } \\
\text { penelitian ini yaitu pasien } \\
\text { COVID-19 dengan skor } \\
\text { pemeriksaan keadaan } \\
\text { minimal }>21 \text {, berusia } 18 \\
\text { tahun ke atas. }\end{array}$ & $\begin{array}{l}\text { Hasil penelitian Yali, } \\
\text { vitamin C dosis tinggi } \\
20 \mathrm{~g} / 60 \mathrm{~kg} / \mathrm{hari} \text {. Penelitian } \\
\text { Zhang et al (2021) } \\
\text { menggunakan dosis besar } \\
\text { vitamin C } 24 \text { g/hari } \\
\text { dengan kecepatan } 12 \\
\text { mL/jam }\end{array}$ \\
\hline
\end{tabular}




\begin{tabular}{|c|c|c|c|c|c|c|}
\hline & & & $\begin{array}{l}\text { perawatan } \\
\text { COVID-19. }\end{array}$ & & & \\
\hline \multirow[t]{14}{*}{4.} & \multirow{14}{*}{$\begin{array}{l}\text { Vitamin C } \\
\text { dosis tinggi } \\
\text { intravena untuk } \\
\text { pengobatan } \\
\text { COVID-19 } \\
\text { yang parah: } \\
\text { protokol } \\
\text { penelitian } \\
\text { untuk uji coba } \\
\text { terkontrol acak } \\
\text { multisenter } \\
\text { (Liu et al., } \\
\text { 2020). }\end{array}$} & \multirow[t]{14}{*}{2020} & \multirow{14}{*}{$\begin{array}{l}\text { Metode uji coba } \\
\text { terkontrol } \\
\text { placebo acak } \\
\text { prospektif } \\
\text { multisenter. }\end{array}$} & Semua & \multirow{4}{*}{ 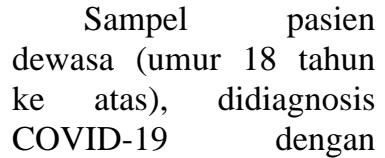 } & Hasil penelitian meta \\
\hline & & & & pasien yang & & analisis sebelumnya \\
\hline & & & & dirawat di 2 & & (Wang et al., 2020) \\
\hline & & & & ICU $\quad(\mathrm{ICU}$ & & menunjukkan bahwa dosis \\
\hline & & & & Zhongnan & diagnosis dan manajemen & tinggi sama atau lebih \\
\hline & & & & Rumah Sakit & klinis pneumonia yang & besar dari $10 \mathrm{~g} /$ hari. \\
\hline & & & & Wuhan dan & terinfeksi, memiliki & Penelitian yang dilakukan \\
\hline & & & & ICU Rumah & indeks kegagalan & (Maggini et al., 2007) \\
\hline & & & & Sakit Leishen & pernapasan $<300 \mathrm{mmHg}$ & dengan dosis tinggi \\
\hline & & & & shan) dari 14 & serta dirawat di ICU. & vitamin C $24 \mathrm{~g} /$ hari pada \\
\hline & & & & Februari & & uji klinis pasien kritis \\
\hline & & & & 2020 hingga & & dengan infeksi berat \\
\hline & & & & 30 & & secara intravena. \\
\hline & & & & $\begin{array}{l}\text { September } \\
2020 .\end{array}$ & & \\
\hline \multirow[t]{13}{*}{5.} & \multirow{13}{*}{$\begin{array}{l}\text { Penggunaan } \\
\text { vitamin C IV } \\
\text { untuk pasien } \\
\text { COVID-19: } \\
\text { rangkaian kasus } \\
\text { (Hiedra } \text { et al., } \\
\text { 2020). }\end{array}$} & \multirow[t]{13}{*}{2020} & \multirow{13}{*}{$\begin{array}{l}\text { Penelitian } \\
\text { dilakukan } \\
\text { dengan } \\
\text { mengidentifikasi } \\
\text { pengobatan dan } \\
\text { menganalisis } \\
\text { demografi dan } \\
\text { klinis. Data } \\
\text { penelitian } \\
\text { dianalisis t-test } \\
\text { berpasangan } \\
\text { serta } \\
\text { menggunakan } \\
\text { Chi- Square. }\end{array}$} & - & \multirow{13}{*}{ 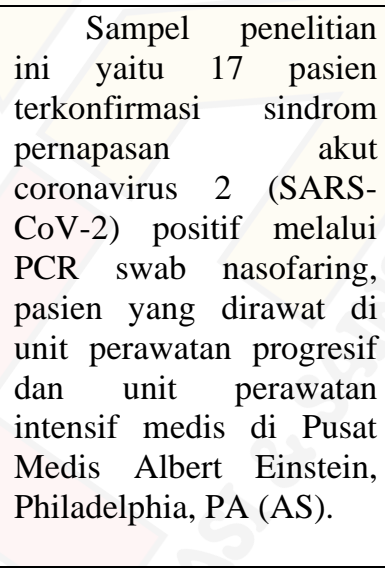 } & \multirow{13}{*}{$\begin{array}{l}\text { Hasil penelitian yang } \\
\text { diperoleh berupa pasien } \\
\text { yang diberikan vitamin C } \\
\text { sebanyak } 1 \mathrm{~g} \text { setiap } 8 \text { jam } \\
\text { selama } 3 \text { hari (dengan } \\
\text { rentang } 0-11 \text { hari) setelah } \\
\text { masuk rumah sakit. }\end{array}$} \\
\hline & & & & & & \\
\hline & & & & & & \\
\hline & & & & & & \\
\hline & & & & & & \\
\hline & & & & & & \\
\hline & & & & & & \\
\hline & & & & & & \\
\hline & & & & & & \\
\hline & & & & & & \\
\hline & & & & & & \\
\hline & & & & & & \\
\hline & & & & & & \\
\hline \multirow[t]{15}{*}{6.} & Vitamin C & \multirow[t]{15}{*}{2021} & \multirow{15}{*}{$\begin{array}{l}\text { Penelitian studi } \\
\text { klinis } \\
\text { retrospektif } \\
\text { berbasis rekam } \\
\text { medis elektronik } \\
\text { sebelum- } \\
\text { sesudah studi } \\
\text { klinis kasus. }\end{array}$} & Semua & \multirow{15}{*}{$\begin{array}{l}\text { Sampelnya yaitu } \\
\text { pasien COVID-19 dengan } \\
\text { diagnosis tipe sedang } \\
\text { pada penerimaan, usia } \\
>18 \text { tahun, tidak hamil, } \\
\text { dan tidak memiliki tumor } \\
\text { ganas. }\end{array}$} & penelitian \\
\hline & Intravena Dosis & & & pasien yang & & berupa kelompok \\
\hline & Tinggi Untuk & & & dirawat & & perlakuan diberikan 100 \\
\hline & Mencegah & & & antara $\quad 18$ & & $\mathrm{mg} / \mathrm{kg} / \mathrm{hari}$ dan meningkat \\
\hline & Perburukkan & & & Maret 2020 & & menjadi $1 \mathrm{~g} / \mathrm{jam}$ selama 7 \\
\hline & Penyakit & & & sampai $\quad 18$ & & hari dari mulai masuk \\
\hline & Pneumonia & & & April 2020 & & rumah sakit, yang \\
\hline & COVID-19 & & & yang & & diberikan secara intravena. \\
\hline & Sedang. & & & menerima & & \\
\hline & Kecenderungan & & & pengobatan & & \\
\hline & Retrospektif & & & HDIVC. & & \\
\hline & Cocok & & & & & \\
\hline & Sebelum- & & & & & \\
\hline & Sesudah Studi & & & & & \\
\hline & $\begin{array}{l}\text { (Zhaoet al., } \\
\text { 2021). }\end{array}$ & & & & & \\
\hline 7. & Pengaruh & 2021 & Penelitian ini & Semua & Pasien dengan & Pasien yang diberikan \\
\hline & Suplementasi & & menggunakan & pasien yang & diagnosis baru dengan & dosis asam askorbat 8000 \\
\hline & Seng dan Asam & & uji coba label & terdaftar. & rawat jalan, berumur 18 & mg (dibagi menjadi 2-3 \\
\hline & Askorbat Dosis & & terbuka klinis & & tahun ke atas, untuk & kali sehari dengan \\
\hline & Tinggi vs & & prospektif acak & & wanita yang & makanan). \\
\hline & Perawatan & & di beberapa & & melahirkan & \\
\hline & Biasa tentang & & rumah sakit. & & memastikan periode & \\
\hline & Panjang Gejala & & & & menstruasi dalam 30 hari & \\
\hline & dan & & & & terakhir dengan hasil & \\
\hline & Pengurangan & & & & perimenopause & \\
\hline & Di Antara & & & & membutuhkan nilai & \\
\hline & Rawat & & & & negatif, pasien yang telah & \\
\hline & Jalan Dengan & & & & keluar dari rumah sakit, & \\
\hline
\end{tabular}




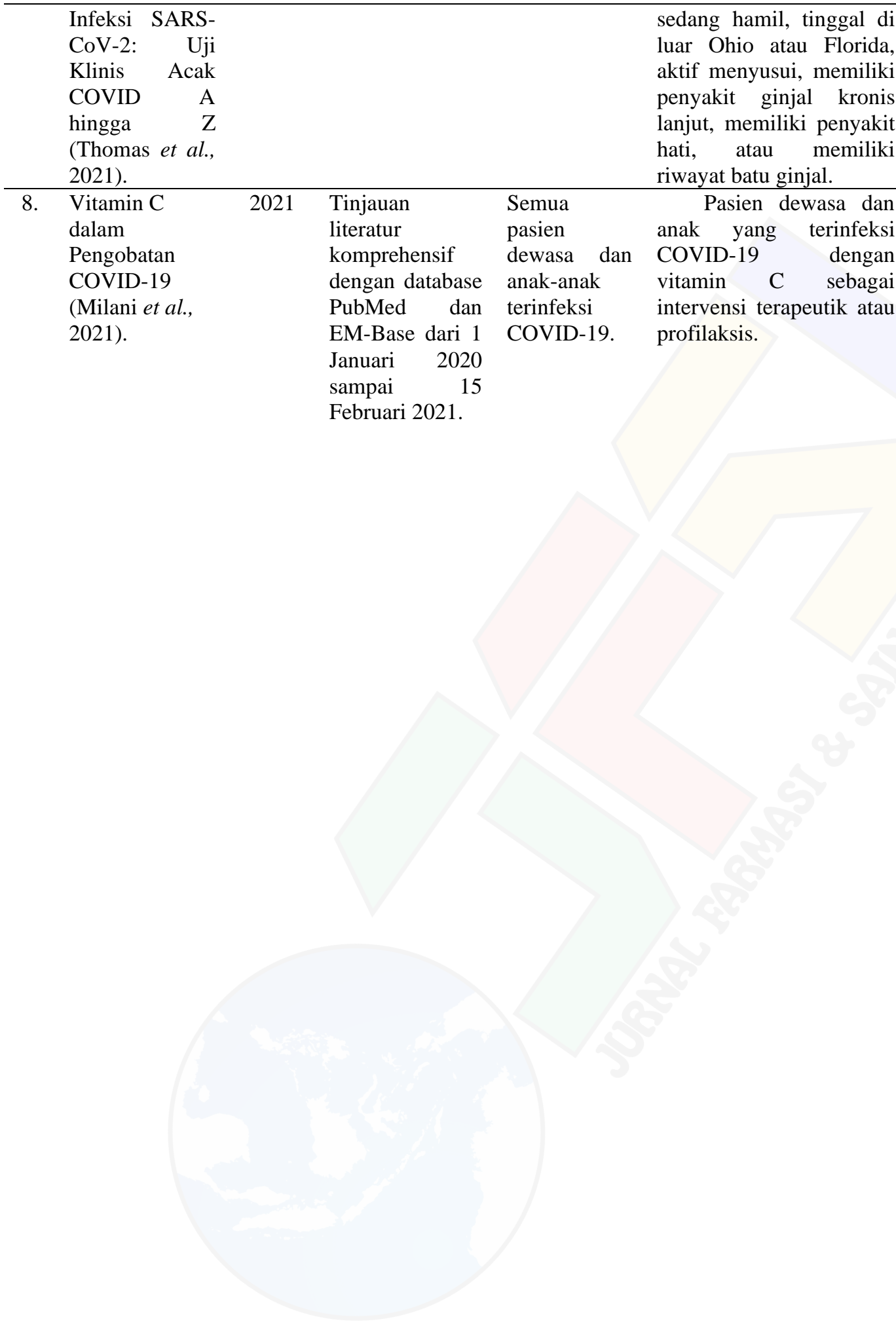

Infeksi SARS

Klinis Acak

COVID A

as et al.

Vitamin C

Pengobatan

COVID-19

(Milani et al. 2021)

$\begin{array}{lr}\text { Tinjauan } & \\ \text { literatur } & \\ \text { komprehensif } & \\ \text { dengan database } \\ \text { PubMed dan } \\ \text { EM-Base dari } 1 \\ \text { Januari } 2020 \\ \text { sampai } \quad 15 \\ \text { Februari } & 2021 .\end{array}$

Semua

intervensi terapeutik atau

profilaksis.

aktif menyusui, memiliki Pasien dewasa dan

Hasil yang diperoleh sebanyak 21 studi yang telah memenuhi seleksi. Dalam penelitian(Khan et al., 2020) pasien COVID19 ARDS menerima vitamin $C$ pertama sebagai dosis oral $1 \mathrm{~g}$ dua kali/hari (selama 6 hari), dan kemudian sebagai dosis intravena (IV) tinggi (dosis: 11 g/hari sebagai infus kontinu, selama 10 hari). Penelitian yang dilakukan (Hiedra et al., 2020) dengan pemberian vitamin C IV (dosis: $1 \mathrm{~g}$ setiap 8 jam, selama 3 hari). (Chen et al., 2021) dengan pasien yang sebelumnya sehat tanpa komorbiditas dengan gejala terkait COVID-19 menerima vitamin $\mathrm{C}$ (dosis: $3 \mathrm{~g}$ sekali sehari) bersama dengan perawatan antivirus dan antimikroba. Penelitian (Bahloul et al., 2020) dengan kasus retrospektif dari 12 pasien dengan pemberian rata-rata vitamin C adalah 162,7 $\mathrm{mg} / \mathrm{kg} / \mathrm{hari} \quad(71,1-328,6)$ dan $178,6 \mathrm{mg}$ /hari. $\mathrm{kg} /$ hari (133,3-350,6).

Sedangkan, penggunaan vitamin C (dosis: $3 \mathrm{~g} / \mathrm{hari}$ ) pada dua pasien dengan infeksi SARS-CoV-2 dan sindrom kebocoran kapiler paru memiliki hasil yang baik.

Uji klinis fase-1 yang dilakukan di Iran (Alamdari et al., 2020) menunjukkan lima pasien dengan pneumonia COVID-19 diberikan kombinasi metilen biruvitamin $\mathrm{C}$ dengan dosis: $1500 \mathrm{mg} / \mathrm{kg}$. 


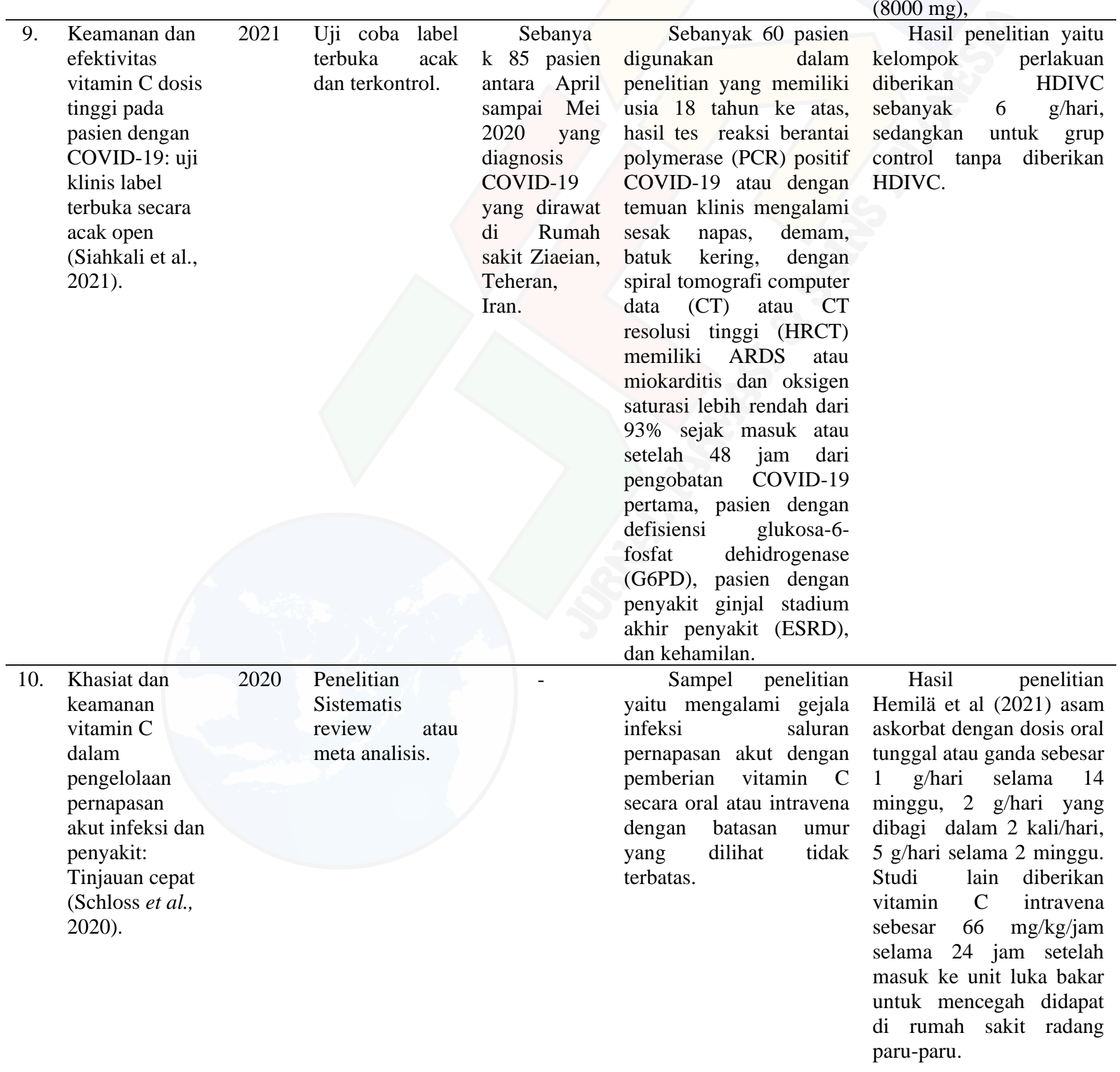

multisenter di Cina

(Alamdari et al., 2020) dengan dosis tinggi vitamin C $12 \mathrm{~g} / 50 \mathrm{~mL}$ setiap 12 jam selama 7 hari, $12 \mathrm{~mL} / \mathrm{jam}$. Dalam RCT label terbuka di Pakistan (Kumari et al., 2020) pasien menerima terapi vitamin C IV dosis: $50 \mathrm{mg} / \mathrm{kg} / \mathrm{hari}$. Dalam RCT multisenter openlabel lain di AS (Kumari et al., 2020) pasien menerima asam askorbat (8000 mg),

efektivitas tinggi pada pasien dengan acak open (Siahkali et al., 2021). resolusi tinggi (HRCT) ARDS ata karditis dan oksigen pengobatan COVID-19 pertama, pasien dengan efisiensi glukosa-6dehidrogenase (G6PD), pasien dengan penyakit ginjal stadium akhir penyakit (ESRD), Sampel penelitian emberian secara oral atau intravena dilihat tidak 
Hal ini, terbukti pada pasien COVID-19 yang diberikan perlakuan sebelum dan sesudah penelitian pada pasien dengan sepsis mengalami penurunan (Maggini et al., 2007). Sehingga, penurunan serum C-reactive protein (CRP) memperjelas bahwa pasien yang mengalami infeksi COVID-19 dengan terapi vitamin C dosis tinggi secara intravena dapat mengurangi inflamasi yang dialami (Hemilä et al., 2021). Keparahan infeksi COVID-19 yang dialami oleh pasien terlihat juga pada tingkat IL-6 yang tinggi menunjukkan sitokin memberikan respons inflamasi. Oleh karena itu, dengan secara konsisten terjadinya penurunan IL-6 menunjukkan vitamin $\mathrm{C}$ secara intravena dengan dosis tinggi mampu menghambat produksi dan pelepasan sitokin proinammatory dari monosit manusia (IL1, IL-2, IL-6, dan TNF- $\alpha$ ) (Hartel et al., 2004). Penelitian menunjukkan bahwa pasien dengan pemberian vitamin $\mathrm{C}$ secara intravena dalam dosis tinggi selama 10 hari setelah gejala dapat memberikan tingkat keberhasilan terapi yang baik (Zhang et al., 2020).

Pasien yang terinfeksi COVID-19 sering mengalami penurunan fungsi pernapasan yang terlihat pada hasil $\mathrm{PiO}_{2} / \mathrm{FiO}_{2}$ yang menunjukkan keparahan infeksi. Pada saluran pernapasan keparahan infeksi menyebabkan terjadi pneumonia, bahkan menyebabkan kegagalan pernapasan pada ARDS yang dapat menjadi penyebab kematian pada pasien dengan COVID19. Terapi vitamin $\mathrm{C}$ mampu untuk mengobati dan mencegah terjadinya radang paru-paru (Williams et al., 2019; Zhao, Liu, et al., 2021). Dilihat dari hasil analisis yang dilakukan terbukti, bahwa terapi vitamin $\mathrm{C}$ dengan dosis tinggi secara intravena memberikan efek terapi dengan terjadi peningkatan fungsi pernapasan yang terlihat pada peningkatan $\mathrm{PiO}_{2} / \mathrm{FiO}_{2}$ (Hartel et al., 2004; Xu et al., 2020; Zhao, Liu, et al., 2021). Dalam memberikan manfaat vitamin $\mathrm{C}$ melakukan mekanisme berupa menghambat terjadinya kenaikan sitokin, tetapi disisi lain vitamin $\mathrm{C}$ memberikan efek perlindungan terhadap paruparu dengan melakukan pemulihan pada epitel, endotel dan alveolar, meningkatkan fungsi sel penghalang paru-paru (Zhao, Liu, et al., 2021). Oleh karena itu, pemberian vitamin C secara intravena dapat meningkatkan ventilasi paru-paru pasien dengan COVID-19. Penelitian menunjukkan bahwa, pemberian terapi vitamin $\mathrm{C}$ dosis tinggi secara intravena memberikan perbaikan terhadap pernapasan pada pasien dengan kondisi berat lebih baik dibandingkan dengan kondisi pasien yang kritis (Alamdari et al., 2020; Chen et al., 2021; Hartel et al., 2004; Zhao, Liu, et al., 2021). Hal ini dimungkinkan karena perbedaan keparahan kondisi pasien, tetapi memperoleh terapi dengan dosis vitamin $\mathrm{C}$ yang hampir sama, tetapi memiliki interval waktu pemberian vitamin $\mathrm{C}$ dosis tinggi secara intravena (Kemenkes RI, 2020).

Limfosit serta sel T CD4+, CD8+, dan CD3+ memiliki hubungan terhadap infeksi COVID-19, jika terjadi penurunan berarti pasien mengalami infeksi yang parah. Hal ini, dikarenakan terjadi penghambatan pada pertumbuhan dan apoptosis sel hematopoietic yang memproduksi antibodi autoimun (Zhang et al., 2020) dan sitokin tertentu (Schloss et al., 2020). Pemberian vitamin C dengan dosis tinggi dapat meningkatkan CD4+ yang lebih baik pada kelompok vitamin $\mathrm{C}$ dosis tinggi (intravena) dibandingkan dengan kelompok kontrol. Selain itu, terjadinya penurunan CRP menyebabkan lama waktu SIRS (systemic inflammatory response syndrome) menjadi lebih pendek, sehingga dapat memulihkan CD4+ menjadi lebih baik pada pasien dengan pemberian vitamin $\mathrm{C}$ secara intravena. Terapi vitamin $\mathrm{C}$ dosis tinggi secara intravena selama 3-7 hari, pasien yang terinfeksi COVID-19 mengalami peningkatan limfosit dan sel T CD4+ (Zhao, Ling, et al., 2021). Hal ini menunjukkan, pasien dengan terapi vitamin $\mathrm{C}$ dosis tinggi secara intravena dapat meningkatkan fungsi imun pasien dengan COVID-19 (Milani et al., 2021; Thomas et al., 2021).

Nilai APTT dan D-dimer diperoleh hasil dengan tingkat yang lebih pendek dan rendah dengan pemberian vitamin $\mathrm{C}$ dosis tinggi secara intravena dibandingkan dengan kelompok kontrol setelah pemberian terapi selama 7 hari. Hal ini menunjukkan bahwa, vitamin $\mathrm{C}$ dosis tinggi secara intravena dapat memberikan efek perbaikan pada kerusakan endotel dengan meningkatkan pembentukan mikrovaskular dan angiopati pada pneumonia COVID-19 (Zhao, Ling, et al., 2021).

Pasien yang terinfeksi COVID-19, tetapi memiliki penyakit komorditas seperti hipertensi, diabetes, dan jantung diberikan terapi vitamin $\mathrm{C}$ 
dosis tinggi secara intravena tidak menunjukkan terjadi perbaikan dengan terapi selama 17 hari. Namun, pemberian terapi vitamin $\mathrm{C}$ dengan dosis tinggi secara intravena dapat menurunkan mortalitas pasien selama 28 hari (Zhang et al., 2020).

Berdasarkan lama rawat inap pasien di ruangan ICU rumah sakit, dapat diketahui bahwa pasien COVID-19 dengan diberikan terapi vitamin C mengalami perawatan ICU yang lebih cepat dibandingkan dengan pasien tanpa terapi vitamin C. Selain itu, menurunkan kematian pasien COVID-19 rawat inap dikarenakan telah terjadi penurunan mekanis ventilasi (Hiedra et al., 2020; Huang et al., 2021).

Pemberian vitamin $\mathrm{C}$ dosis tinggi secara intravena menunjukkan dapat meningkatkan daya tahan sel darah putih terhadap virus dikarenakan efek antioksidan yang dimiliki dan kemampuan untuk menginduksi interferon produksi in vivo (Fowler et al., 2019; Kirchdoerfer et al., 2016). Oleh karena itu, vitamin $\mathrm{C}$ memiliki manfaat meningkatkan efektivitas pengobatan pada pasien dengan infeksi COVID-19. Penelitian menunjukkan, penggunaan vitamin $\mathrm{C}$ secara intravena mungkin aman dan dapat digunakan pada pasien dengan kondisi sedang ataupun parah. Namun, tidak direkomendasikan untuk mengurangi gejala yang dialami oleh pasien yang terinfeksi. Dalam melakukan penelitian pengobatan dengan vitamin $\mathrm{C}$ diperlukan waktu yang tidak sedikit, tetapi dikarenakan terdapat jumlah pasien yang memadai dengan analisis cermat dapat memberikan stabilitas, ketersediaan, keamanan dan biaya yang lebih besar dibandingkan dengan pengobatan menggunakan plasma darah (Huang et al., 2021). Akan tetapi, penelitian lain menunjukkan pemberian vitamin $\mathrm{C}$ tidak dapat memperbaiki kondisi pasien kritis, maupun pneumonia. Sehingga, diperlukan penelitian lanjutan yang menunjukkan tidak terdapat perbedaan antara pasien diberikan vitamin $\mathrm{C}$ secara intravena dengan hanya diberikan terapi COVID-19 (Milani et al., 2021). Pemberian vitamin C secara intravena belum ditemukan terjadinya efek samping (Hiedra et al., 2020).

\section{Kesimpulan}

Berdasarkan review 10 jurnal di atas, dapat disimpulkan bahwa pemberian vitamin $\mathrm{C}$ dosis tinggi secara intravena dapat memperbaiki kehidupan klinis pasien COVID-19. Hal tersebut terlihat dari dihambatnya perkembangan dari sitokin dan meningkatkan limfosit serta sel $\mathrm{T}$ CD4+, meningkatkan fungsi pernapasan pasien dengan terjadi peningkatan pada $\mathrm{PiO}_{2} / \mathrm{FiO}_{2}$ serta nilai APTT dan D-dimer yang rendah. Hal ini, dikarenakan efek imunomodulator yang dimiliki oleh vitamin $\mathrm{C}$. Pemberian vitamin $\mathrm{C}$ secara intravena memiliki mekanis menurunkan kenaikan sitokin, meningkatkan pembersihan cairan alveolar, mencegah cedera vaskular, memulihkan integritas epitel endotel serta alveolar dan meningkatkan fungsi penghalang dari paru-paru.

\section{Daftar Pustaka}

Alamdari, D. H., Moghaddam, A. B., Amini, S., Keramati, M. R., Zarmehri, A. M., Alamdari, A. H., Damsaz, M., Banpour, H., Yarahmadi, A., \& Koliakos, G. (2020). Application of methylene blue -vitamin C -N-acetyl cysteine for treatment of critically ill COVID-19 patients, report of a phase-I clinical trial. European Journal of Pharmacology, 885, 1-6. https://doi.org/10.1016/j.ejphar.2020.173494

Bahloul, M., Ketata, W., Lahyeni, D., Mayoufi, H., Kotti, A., Smaoui, F., Kallel, N., Daoud, E., Bouaziz, M., \& Kammoun, S. (2020). Pulmonary capillary leak syndrome following COVID-19 virus infection. Journal of Medical Virology, 93, 94-96. https://doi.org/10.1002/jmv.26152

Chen, Y., Chen, W., Zhou, J., Sun, C., \& Lei, Y. (2021). Large pulmonary cavity in COVID19 cured patient case report. Ann Palliat Med, 10(5), 5786-5791. https://doi.org/10.21037/apm-20-452

Fowler, A. A., Truwit, J. D., Hite, R. D., Morris, P. E., DeWilde, C., Priday, A., \& Fisher, B. (2019). Effect of Vitamin C Infusion on Organ Failure and Biomarkers of Inflammation and Vascular Injury in Patients With Sepsis and Severe Acute Respiratory Failure: The CITRIS-ALI Randomized Clinical Trial. JAMA, 322(13), 1261-1270. 
https://doi.org/10.1001/jama.2019.11825

Hartel, C., Strunk, T., Bucsky, P., \& Schultz, C. (2004). Effects of vitamin $\mathrm{C}$ on intracytoplasmic cytokine production in human whole blood monocytes and lymphocytes. National Library of Medicine, 27(4-5), 101-106. https://doi.org/https://doi.org/10.1016/j.cyto. 2004.02.004.

Hemilä, H., Carr, A., \& Chalker, E. (2021). Vitamin C May Increase the Recovery Rate of Outpatient Cases of SARS-CoV-2 Infection by 70\%: Reanalysis of the COVID A to Z Randomized Clinical Trial. Frontiers in Immunology, 12(May), 10-13. https://doi.org/10.3389/fimmu.2021.674681

Hidayah, S. N., Izah, N., \& Andari, I. D. (2020). Peningkatan Imunitas dengan Konsumsi Vitamin C dan Gizi Seimbang Bagi Ibu Hamil Untuk Cegah Corona Di Kota Tegal. Jurnal ABDINUS: Jurnal Pengabdian Nusantara, 4(1 SE-Artikel), 170-174. https://ojs.unpkediri.ac.id/index.php/PPM/art icle/view/14641

Hiedra, R., Lo, K. B., Elbashabsheh, M., Gul, F., Wright, R. M., Albano, J., Azmaiprashvili, Z., \& Patarroyo Aponte, G. (2020). The Use of IV vitamin C for patients with COVID-19: a single center observational study. Expert Review of Anti-Infective Therapy, 00(00), 13.

https://doi.org/10.1080/14787210.2020.1794 819

Huang, L., Wang, L., Tan, J., Liu, H., \& Ni, Y. (2021). High-dose vitamin C intravenous infusion in the treatment of patients with COVID-19: A protocol for systematic review and meta-analysis. Medicine, 100(19), e25876.

https://doi.org/10.1097/MD.00000000000258 76

Kemenkes RI. (2020). Pedoman Kesiapsiagaan Menghadapi Coronavirus Disease (COVID19). In L. Aziza, A. Aqmarina, \& M. Ihsan (Eds.), Direktorat jenderal Pencegahan dan pengendalian Penyakit. Kementerian Kesehatan Republik Indonesia. http://fe.unj.ac.id/wpcontent/uploads/2020/03/REV-

02_Pedoman_Kesiapsiagaan_COVID-19_-
Ver-17-Feb-2020-fix-1.pdf

Khan, H. M. W., Parikh, N., Megala, S. M., \& Predeteanu, G. S. (2020). Unusual Early Recovery of a Critical COVID-19 Patient After Administration of Intravenous Vitamin C. $A M \quad J$ Case, 21, 1-6. https://doi.org/10.12659/AJCR.925521

Kirchdoerfer, R. N., Cottrell, C. A., Wang, N., Pallesen, J., Yassine, H. M., Turner, H. L., Corbett, K. S., Graham, B. S., McLellan, J. S., \& Ward, A. B. (2016). Pre-fusion structure of a human coronavirus spike protein. Nature, 531(7592), 118-121. https://doi.org/10.1038/nature17200

Kumari, P., Dembra, S., Dembra, P., Bhawna, F., Gul, A., Ali, B., Sohail, H., Kumar, B., Memon, M. K., \& Rizwan, A. (2020). The Role of Vitamin C as Adjuvant Therapy in COVID-19. Creative Commons Attribution License, 12(11), 10-13. https://doi.org/10.7759/cureus.11779

Liu, F., Zhu, Y., Zhang, J., Li, Y., \& Peng, Z. (2020). Intravenous high-dose vitamin C for the treatment of severe COVID-19: Study protocol for a multicentre randomised controlled trial. BMJ Open, 10(7). https://doi.org/10.1136/bmjopen-2020039519

Maggini, S., Wintergerst, E. S., Beveridge, S., \& Hornig, D. H. (2007). Selected vitamins and trace elements support immune function by strengthening epithelial barriers and cellular and humoral immune responses. British Journal of Nutrition, 98(SUPPL. 1), 29-35. https://doi.org/10.1017/S0007114507832971

Milani, G. P., Macchi, M., \& Guz-Mark, A. (2021). Vitamin c in the treatment of covid19. Nutrients, 13(4), 1-10. https://doi.org/10.3390/nu13041172

Rahman, S., \& Bahar, T. (2020). COVID-19: The New Threat. International Journal of Infection, 7(1), 1-6. https://doi.org/10.5812/iji.102184

Rothan, H. A., \& Byrareddy, S. N. (2020). Review article The epidemiology and pathogenesis of coronavirus disease (COVID-19) outbreak. Journal of Autoimmunity, 109, 1-4. https://doi.org/10.1016/j.jaut.2020.102433

Schloss, J., Lauche, R., Harnett, J., Hannan, N., 
Brown, D., Green, T., \& Steel, A. (2020). Efficacy and safety of vitamin $\mathrm{C}$ in the management of acute respiratory infection and disease: A rapid review. Advances in Integrative Medicine, 7(4), 187-191. https://doi.org/10.1016/j.aimed.2020.07.008

Siahkali, S. J. M., Zarezade, B., Koolaji, S., SeyedAlinaghi, S. A., Zendehdel, A., Tabarestani, M., Sekhavati Moghadam, E., Abbasian, L., Dehghan Manshadi, S. A., Salehi, M., Hasannezhad, M., Ghaderkhani, S., Meidani, M., Salahshour, F., Jafari, F., Manafi, N., \& Ghiasvand, F. (2021). Safety and effectiveness of high-dose vitamin $\mathrm{C}$ in patients with COVID-19: a randomized open-label clinical trial. European Journal of Medical Research, 26(1), 1-9. https://doi.org/10.1186/s40001-021-00490-1

Thomas, S., Patel, D., Bittel, B., Wolski, K., Wang, Q., Kumar, A., Il'Giovine, Z. J., Mehra, R., McWilliams, C., Nissen, S. E., \& Desai, M. Y. (2021). Effect of High-Dose Zinc and Ascorbic Acid Supplementation vs Usual Care on Symptom Length and Reduction among Ambulatory Patients with SARS-CoV-2 Infection: The COVID A to Z Randomized Clinical Trial. JAMA Network Open, 4(2), 1-10. https://doi.org/10.1001/jamanetworkopen.20 21.0369

Wang, D., Hu, B., Hu, C., Zhu, F., Liu, X., Zhang, J., Wang, B., Xiang, H., Cheng, Z., Xiong, Y., Zhao, Y., Li, Y., Wang, X., \& Peng, Z. (2020). Clinical Characteristics of 138 Hospitalized Patients With 2019 Novel Coronavirus-Infected Pneumonia in Wuhan, China. JAMA, 323(11), 1061-1069. https://doi.org/10.1001/jama.2020.1585

Williams, A. M., Ladva, C. N., Leon, J. S., Lopman, B. A., Tangpricha, V., \& Whitehead, R. D. (2019). Changes in micronutrient and inflammation serum biomarker concentrations after a norovirus human challenge. Am J Clin Nut, 110, 14561464. https://doi.org/10.1093/ajcn/nqz201

Xu, B., Fan, C., Wang, A., Zou, Y., Yu, Y., \& He, C. (2020). Suppressed T cell-mediated immunity in patients with COVID-19: A clinical retrospective study in Wuhan, China. Journal of Infection, 81, 51-60. https://doi.org/10.1016/j.jinf.2020.04.012

Yang, J., Zheng, Y., Gou, X., Pu, K., Chen, Z., \& Guo, Q. (2020). Prevalence of comorbidities and its effects in patients infected with SARS-CoV-2: a systematic review and metaanalysis. International Journal of Infectious Diseases, 94, 91-95. https://doi.org/10.1016/j.ijid.2020.03.017

Zhang, J., Rao, X., Li, Y., Zhu, Y., Guo, G., Luo, G., Hospital, T., Meng, Z., De Backer, D., Xiang, H., \& Peng, Z.-Y. (2020). High-dose vitamin $C$ infusion for the treatment of critically ill COVID-19. Research Square, 123.

https://doi.org/https://doi.org/10.21203/rs.3.rs $-52778 / \mathrm{v} 1$

Zhang, J., Rao, X., Li, Y., Zhu, Y., Liu, F., Guo, G., Luo, G., Meng, Z., De Backer, D., Xiang, H., \& Peng, Z. (2021). Pilot trial of high-dose vitamin C in critically ill COVID-19 patients. Annals of Intensive Care, 11(1), 1-25. https://doi.org/10.1186/s13613-020-00792-3

Zhao, B., Ling, Y., Li, J., Peng, Y., Huang, J., Wang, Y., Qu, H., Gao, Y., Li, Y., Hu, B., Lu, S., Lu, H., Zhang, W., \& Mao, E. (2021). Beneficial aspects of high dose intravenous vitamin $\mathrm{C}$ on patients with COVID-19 pneumonia in severe condition: a retrospective case series study. Annals of Palliative Medicine, 10(2), 1599-1609. https://doi.org/10.21037/apm-20-1387

Zhao, B., Liu, M., Liu, P., Peng, Y., Huang, J., Li, M., Wang, Y., Xu, L. L., Sun, S., Qi, X., Ling, Y., Li, J., Zhang, W., Mao, E., \& Qu, J. (2021). High Dose Intravenous Vitamin C for Preventing The Disease Aggravation of Moderate COVID-19 Pneumonia. A Retrospective Propensity Matched BeforeAfter Study. Frontiers in Pharmacology, 12(April), 1-9. https://doi.org/10.3389/fphar.2021.638556 